medRxiv preprint doi: https://doi.org/10.1101/2020.04.20.20072793; this version posted April 24, 2020. The copyright holder for this preprint (which was not certified by peer review) is the author/funder, who has granted medRxiv a license to display the preprint in perpetuity. It is made available under a CC-BY-NC-ND 4.0 International license .

\title{
Prediction of the Peak, Effect of Intervention and Total Infected by the Coronavirus
}

\section{Disease in India}

\section{Parth Vipul Shah [Corresponding Author]}

Email: parthvipulshah@pesu.pes.edu

Address: PES Univeristy, 100 Feet Road, BSK III Stage, Bangalore 560085, India

(Dated: 20 April 2020) 
medRxiv preprint doi: https://doi.org/10.1101/2020.04.20.20072793; this version posted April 24, 2020. The copyright holder for this preprint (which was not certified by peer review) is the author/funder, who has granted medRxiv a license to display the preprint in perpetuity. It is made available under a CC-BY-NC-ND 4.0 International license .

\begin{abstract}
We study the effect of the coronavirus disease 2019 (COVID-19) in India using the SEIR compartmental model. After it's outbreak in Wuhan, China, it has been imported to India which is a densely populated country. India is fighting against this disease by ensuring nationwide social distancing. We estimate the infection rate to be 0.258 using a least square method with Poisson noise and estimate the reproduction number to be 2.58. We approximate the peak of the epidemic to be August 11, 2020. We estimate that a $25 \%$ drop in infection rate will delay the peak by 38 days for a 1 month intervention period. We estimate that the total individuals infected in India will be approximately $9 \%$ of the total population.
\end{abstract}

Keywords: COVID-19; SEIR compartmental model; India; infection rate; peak prediction; intervention

\title{
I. INTRODUCTION
}

In this work, on the eve of the outbreak of the deadly coronavirus disease 2019 (COVID$19)^{1}$ in India, caused by severe acute respiratory syndrome coronavirus $2(\mathrm{SARS}-\mathrm{CoV}-2)^{2}$, we predict the peak of the epidemic, effect of intervention and total individuals infected. This disease has demonstrated person-to-person transmission ${ }^{3}$ and as India is a densely populated country, it is necessary to understand the effects of this disease to mitigate its risk. January 30, 2020 marked the first identified case of COVID-19 in India. ${ }^{4}$ Meanwhile COVID-19 has spread around the world. As of March 22, 2020, Italy has approximately 59 thousand confirmed cases, USA has approximately 34 thousand confirmed cases and Spain has approximately 29 thousand confirmed cases. India has only a total of 66 confirmed cases. $\frac{4}{4}$ The World Health Organization (WHO) declared the disease a pandemic on March 11, 2020 The total number of confirmed cases in India and the daily increase in cases is depicted below in Figures 1 and 2 . 
medRxiv preprint doi: https://doi.org/10.1101/2020.04.20.20072793; this version posted April 24, 2020. The copyright holder for this preprint (which was not certified by peer review) is the author/funder, who has granted medRxiv a license to display the preprint in perpetuity.

It is made available under a CC-BY-NC-ND 4.0 International license .

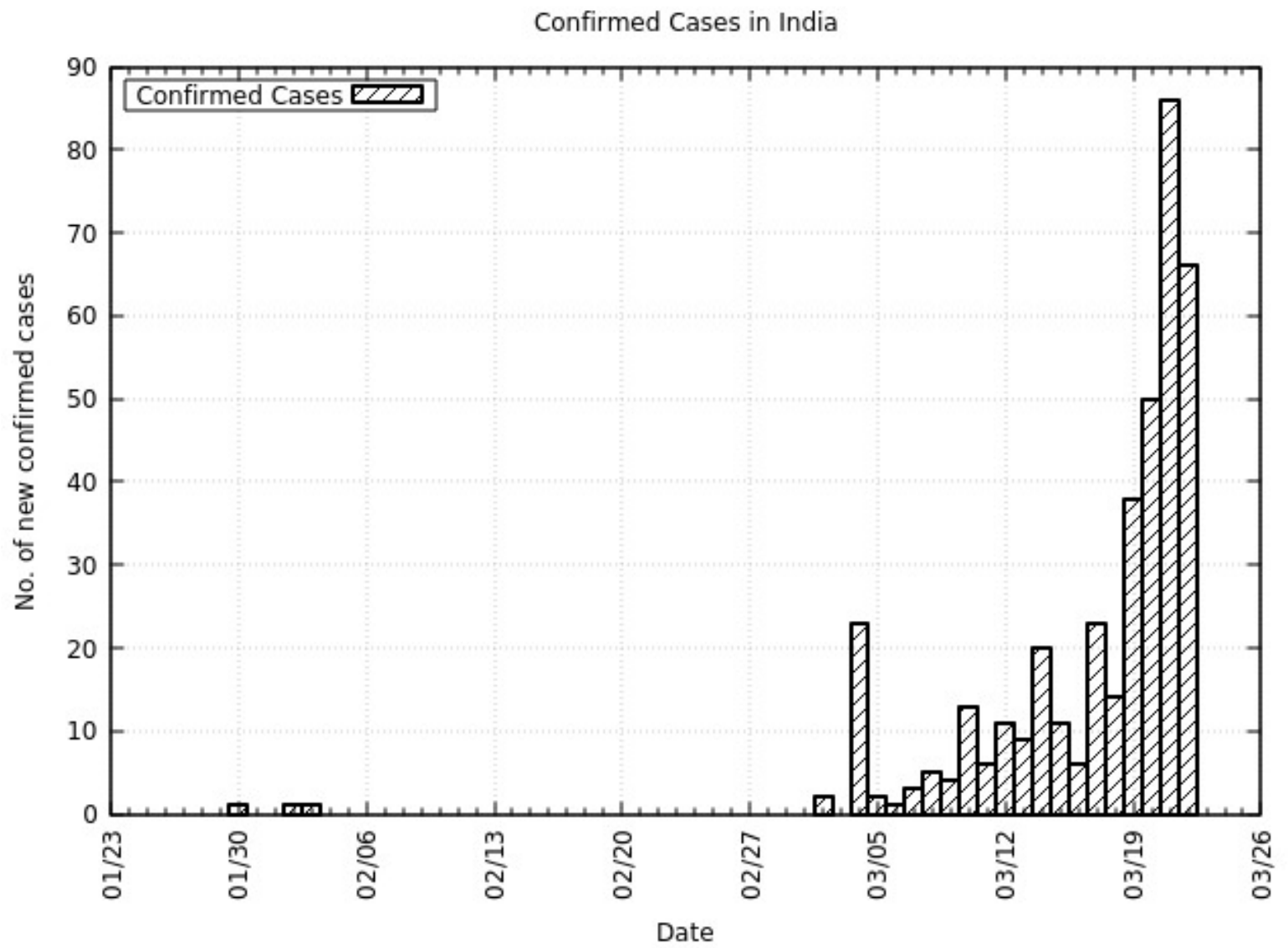

FIG. 1: Daily increase in confirmed cases of COVID-19 in India. Day 0 is January 22, 2020 and day 52 is March 22, 2020. Data is taken from Center for Systems Science and Engineering (CSSE) at Johns Hopkins University (JHU)! 


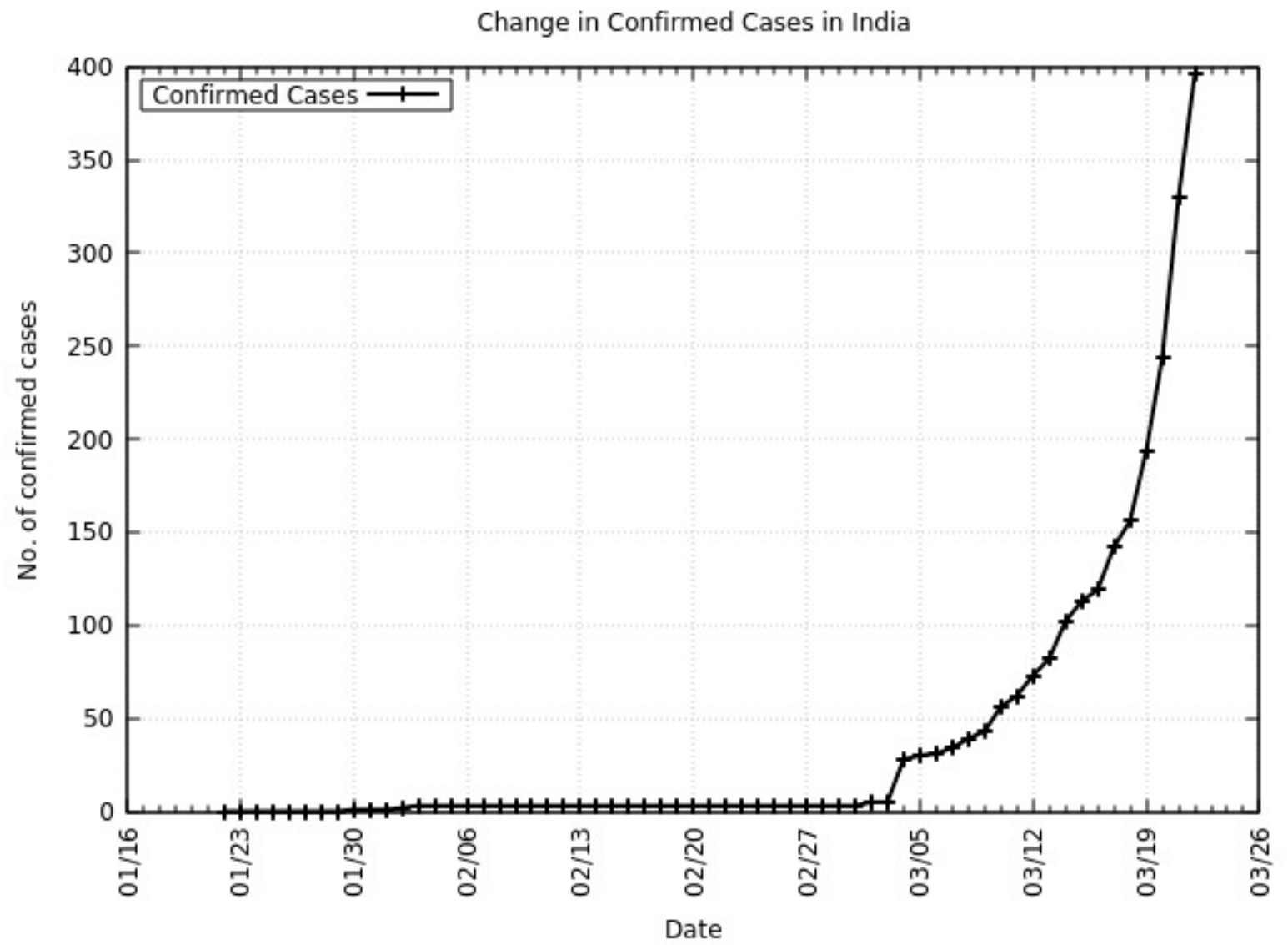

FIG. 2: Cumulative confirmed cases of COVID-19 in India. Day 0 is January 22, 2020 and day 52 is March 22, 2020. Data is taken from Center for Systems Science and Engineering (CSSE) at Johns Hopkins University (JHU)!

The growth of the number of confirmed COVID-19 cases can be approximated by an exponential function. The growth factor $r$ at day $t$ can be calculated as

$$
r=\frac{\text { Cases on day } \mathrm{t}}{\text { Cases on day } \mathrm{t}-1}
$$

TABLE I: Growth Factor, r

\begin{tabular}{lccc}
\hline \hline Date & Day & No. of confirmed cases & Growth factor, r \\
\hline March 18 & 48 & 14 & - \\
March 19 & 49 & 38 & 2.714 \\
March 20 & 50 & 50 & 1.315 \\
March 21 & 51 & 86 & 1.720 \\
\hline \hline
\end{tabular}


medRxiv preprint doi: https://doi.org/10.1101/2020.04.20.20072793; this version posted April 24, 2020. The copyright holder for this preprint

(which was not certified by peer review) is the author/funder, who has granted medRxiv a license to display the preprint in perpetuity.

It is made available under a CC-BY-NC-ND 4.0 International license .

March 22, 2020, India is reporting an average growth rate of 1.916 calculated over the past 4 days (refer to Table I). Stricter rules and measures of ensuring social distancing have begun [6] India is fighting this disease by ensuring nation-wide lock-down and social distancing when the number of infected individuals are low. All non-essential workers across all industries have been given stay at home orders.

\section{METHODS}

\section{A. Model}

The SEIR compartmental model has been used to model previous pandemics in the field of Epidemiology. It is applied on the data from India based on a recent publication ${ }^{7}$ which applied it on the data from Japan. The same methodology is adopted here. The assumption that once an individual contracts the virus and recovers, the individual is immune to this virus is assumed. The SEIR model is defined in Equation 2.

$$
\begin{aligned}
& S^{\prime}(t)=-\beta S(t) I(t) \\
& E^{\prime}(t)=\beta S(t) I(t)-\epsilon E(t) \\
& I^{\prime}(t)=\epsilon E(t)-\gamma I(t) \\
& R^{\prime}(t)=\gamma I(t)
\end{aligned}
$$

The susceptible, exposed, infected and removed populations at time $\mathrm{t}$ is denoted by $S(t), E(t), I(t), R(t)$ respectively. The infection rate, the onset rate and the removal rate is denoted by $\beta, \epsilon, \gamma$ respectively. The average incubation period and the average infectious period is $1 / \epsilon$ and $1 / \gamma$ respectively. We fix $1 / \epsilon$ to 5 and $1 / \gamma$ to 10 based on recent publications that have studied the average incubation period and the average infectious period. ${ }^{[0]}$ The unit time is 1 day. The fraction of infected individuals that can be identified by diagnosis is denoted by $p$. We also fix $S+E+I+R$ to 1 so that calculations are a proportion of the total population. The total population of India, $\mathrm{N}$ is fixed at 1.33 billion. 10 The assumption that 1 individual amongst a total population of $\mathrm{N}\left(1339.2 \times 10^{6}\right)$ individuals is identified as infected at $t=0$ is adopted. Therefore the total number of infected individuals who are identified at time $\mathrm{t}$ is given by the product of fraction of individuals that can be identified by diagnosis, infected individuals at time $\mathrm{t}$ and the total population (Equation 3). 


$$
Y(t)=p I(t) \times N
$$

To obtain the initial conditions of the model, we assume that there are no exposed or removed populations at $t=0$.

$$
\begin{aligned}
& E(0)=0 \\
& I(0)=\frac{1}{p \times N} \\
& R(0)=0 \\
& S(0)=1-E(0)-I(0)-R(0)=1-\frac{1}{p \times N}
\end{aligned}
$$

are the initial conditions. We fix $0.01<p<0.1$ based on government reports of the density of affected people in a particular region. 11 The expected value of secondary cases produced by one infected individual, the reproduction number, $R_{0}$ is calculated from Equation 5.12

$$
R_{0}=\frac{\beta S(0)}{\gamma}=\frac{\beta}{\gamma}\left(1-\frac{1}{p \times N}\right)
$$

Using this model, we estimate the infection rate, $\beta$ in the next section.

\section{B. Estimation of the infection rate, $\beta$}

Let $y(t), t=0,1,2 \ldots 52$ be the daily confirmed cases of COVID-19 in India from January 22, $2020(t=0)$ to March 22, $2020(t=52)$. Using the least square approach with Poisson noise to estimate the infection rate, the following steps are adopted. With Poisson noise, Equation 3 is modified to

$$
\hat{Y}(t)=Y(t)+\sqrt{Y(t)} \epsilon(t)
$$

$\epsilon(t), t=0,1,2 \ldots 52$ are random variables from a standard normal distribution. The following steps are adopted to estimate $\beta$.

1. For $\beta>0$, calculate $Y(t), t=0,1,2 \ldots 52$ using Equation 3 .

2. Calculate $\hat{Y}$ using Equation 6 . 
3. Calculate $J(\beta)=\sum_{t=0}^{52}[y(t)-\hat{Y}(t)]^{2}$

4. Run step 1 to step 3 for $0.2 \leq \beta \leq 0.4$ and find $\beta^{*}$ such that $J\left(\beta^{*}\right)=\min _{0.2 \leq \beta \leq 0.4} J(\beta)$

5. Repeat step 1 to step 4, 10000 times and obtain the distribution of $\beta^{*}$. Approximate the same by a normal distribution and obtain the $95 \%$ confidence interval.

We obtain a value of $\beta$ equal to 0.258 and the $95 \%$ confidence interval as $0.250-0.266$. Also, $R_{0}$ is equal to 2.58 and the $95 \%$ confidence interval as $2.50-2.66$. This is represented in Figure 3 with an overlap of the number of new confirmed cases. A summary of all parameters can be found in Table II.

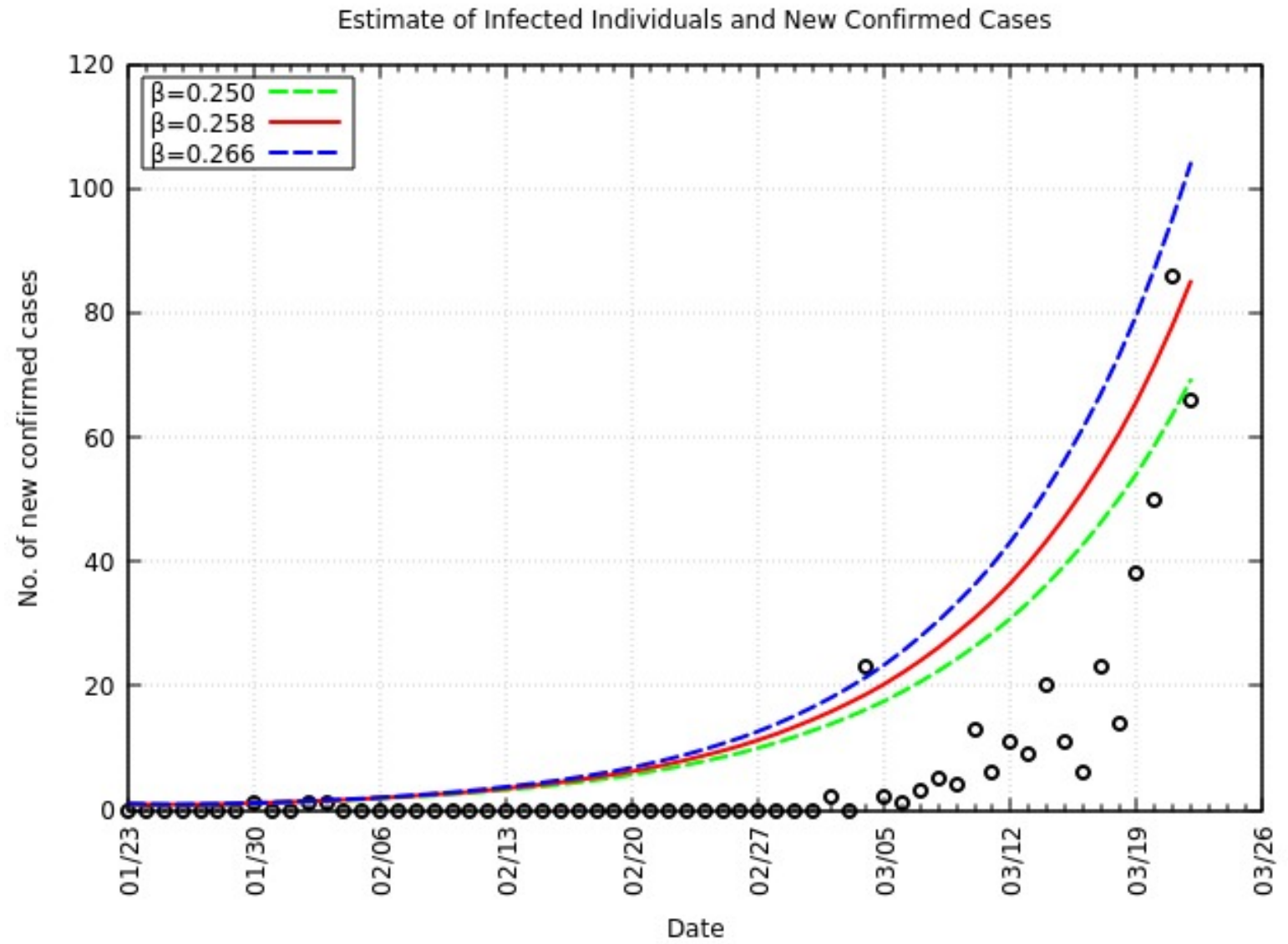

FIG. 3: Comparison of daily confirmed cases and $Y$ in India from $t=0$ to $t=52$ 
TABLE II: Parameters

\begin{tabular}{clc}
\hline \hline Parameter & Description & Value \\
\hline$\beta$ & Infection rate & 0.258 \\
$R_{0}$ & Reproduction number & 2.58 \\
$\epsilon$ & Onset rate & 0.2 \\
$\gamma$ & Removal rate & 0.1 \\
$N$ & Total population of India & $1339.2 \times 10^{6}$ \\
$p$ & Identification rate & $0.01-0.1$ \\
\hline \hline
\end{tabular}

\section{RESULTS}

\section{A. Peak Prediction}

The epidemic peak, $t^{*}$ is defined as the day $\mathrm{t}$ when the maximum value $Y$ in a period of 550 days is achieved. As an expression, $Y\left(t^{*}\right)=\max _{0 \leq t \leq 550}$. As the epidemic peak and size are sensitive to the identification rate $\mathrm{p}$, we report the following.

For $p=0.1$, the estimated peak is $t^{*}=229$ with a $95 \%$ confidence interval of 221 238. That is, starting from January 22, $2020(t=0)$, the estimated peak is September 7 , $2020(t=229)$ and interval ranging from August 30, 2020 to September 16, 2020. This is represented in Figure 4 . 


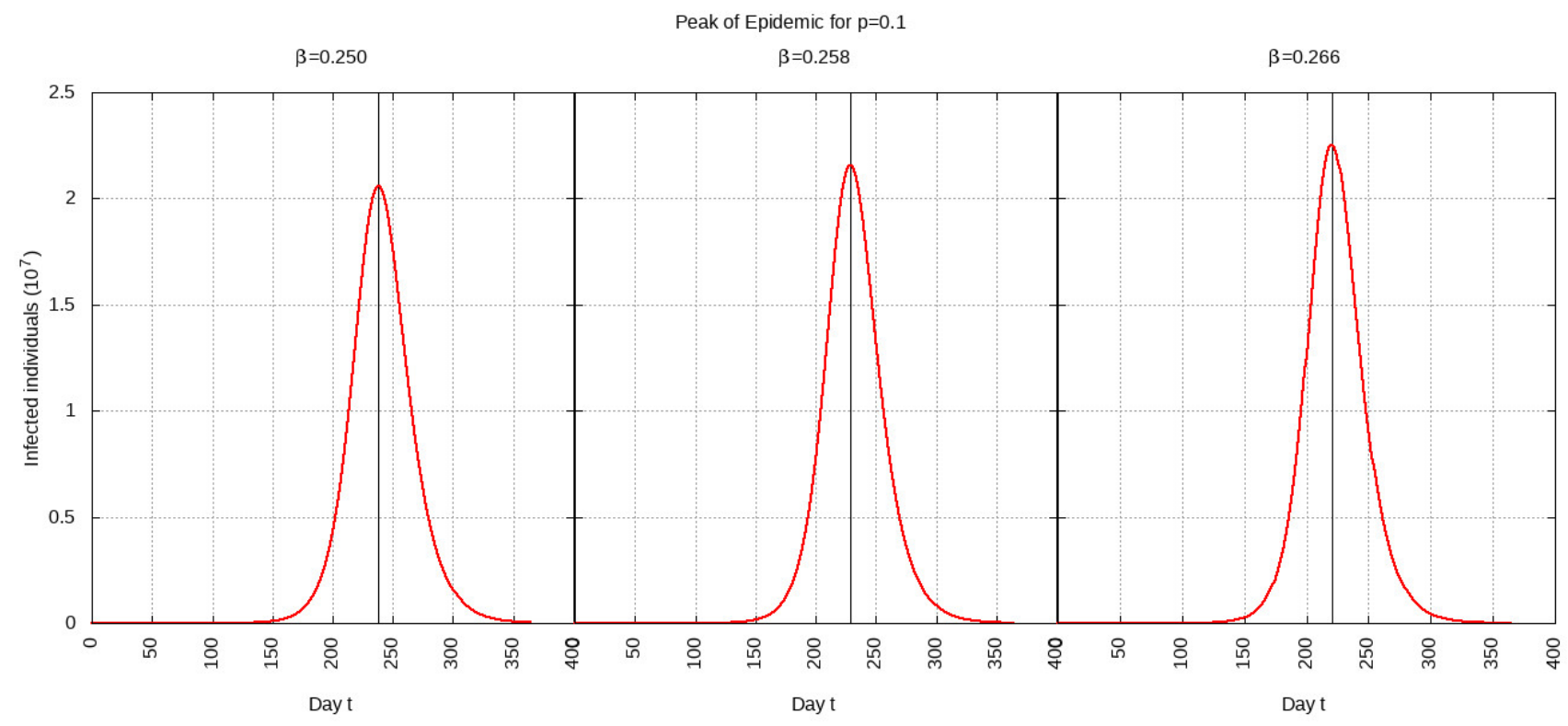

FIG. 4: Infected individuals for time t, $0 \leq t \leq 550$ for $p=0.1$

For $p=0.01$, the estimated peak is $t^{*}=202$ with a $95 \%$ confidence interval of 194-210. That is, starting with January 22, $2020(t=0)$, the estimated peak is August 11, 2020 $(t=202)$ and interval ranging from August 3, 2020 to August 19, 2020. This is represented in Figure 5 .

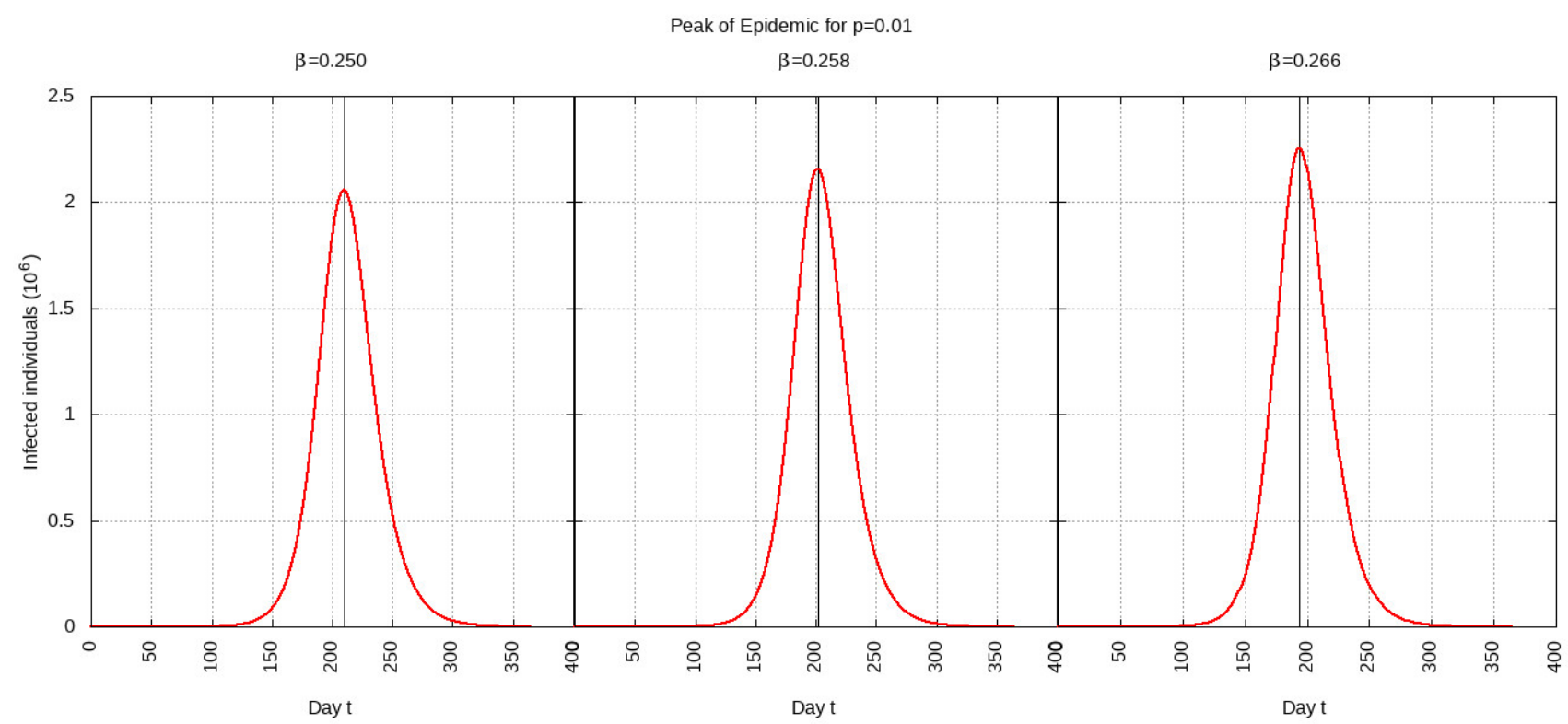

FIG. 5: Infected individuals for time t, $0 \leq t \leq 550$ for $p=0.01$ 
medRxiv preprint doi: https://doi.org/10.1101/2020.04.20.20072793; this version posted April 24, 2020. The copyright holder for this preprint (which was not certified by peer review) is the author/funder, who has granted medRxiv a license to display the preprint in perpetuity.

\section{B. Effect of Intervention}

India has announced a 21 day complete shutdown starting March 25, 2020!13 For our calculations, we assume that this shutdown will reduce the infection rate to $75 \%, 50 \%$ or $25 \%$ of its original value of 0.258 . For each reduction in infection rate, the effect of an intervention period of 30 days (one month) and 180 days (six months) is calculated. The government of India maintains that the third stage or community transmission has not begun. 14 The current identification rate is low due to the low number of COVID-19 tests being conducted ${ }^{15}$ Therefor, we set $\mathrm{p}$ to 0.01 as the current identification rate is low. This closely matches available data too.

\section{1. $75 \%$ Reduction in Infection Rate}

For a $75 \%$ reduction in the infection rate and one month of intervention, the estimated peak is delayed by 12 days. That is, pushed from 202 days to 214 days since day 0 (January $30,2020)$. For a $75 \%$ reduction in the infection rate and six months of intervention, the estimated peak is delayed by 68 days. That is, pushed from 202 days to 270 days since day 0 (January 30, 2020). These are represented in Figure 6. 


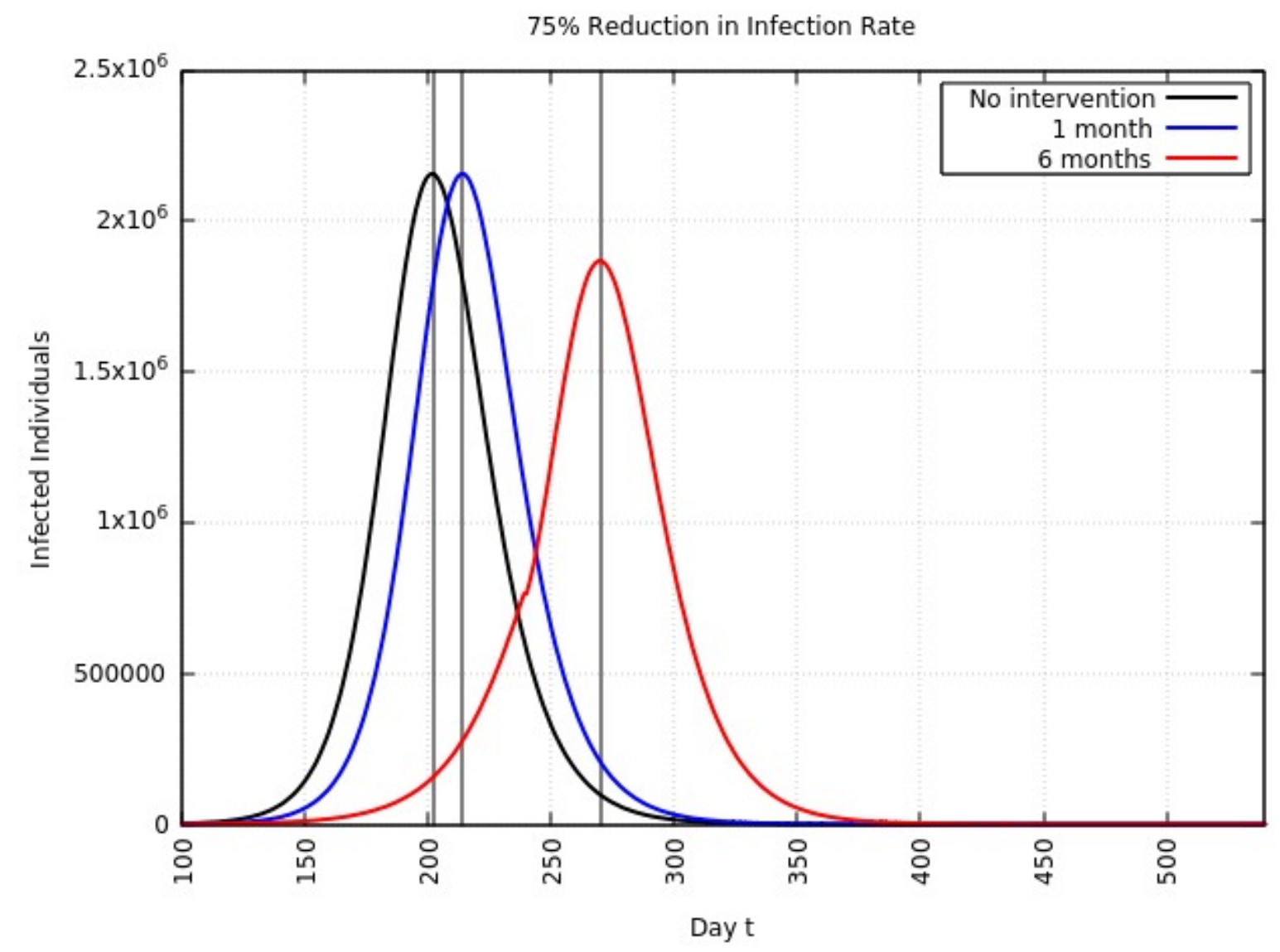

FIG. 6: Variation in $Y(t)$ for time t, $0 \leq t \leq 550$ with no intervention, 1 month of intervention and 6 months of intervention with assumption of $\beta=0.75 \times 0.258$

\section{2. $50 \%$ Reduction in Infection Rate}

For a $50 \%$ reduction in the infection rate and one month of intervention, the estimated peak is delayed by 24 days. That is, pushed from 202 days to 226 days since day 0 (January $30,2020)$. For a $50 \%$ reduction in the infection rate and six months of intervention, the estimated peak is delayed by 141 days. That is, pushed from 202 days to 343 days since day 0 (January 30, 2020). This is represented in Figure 7. 


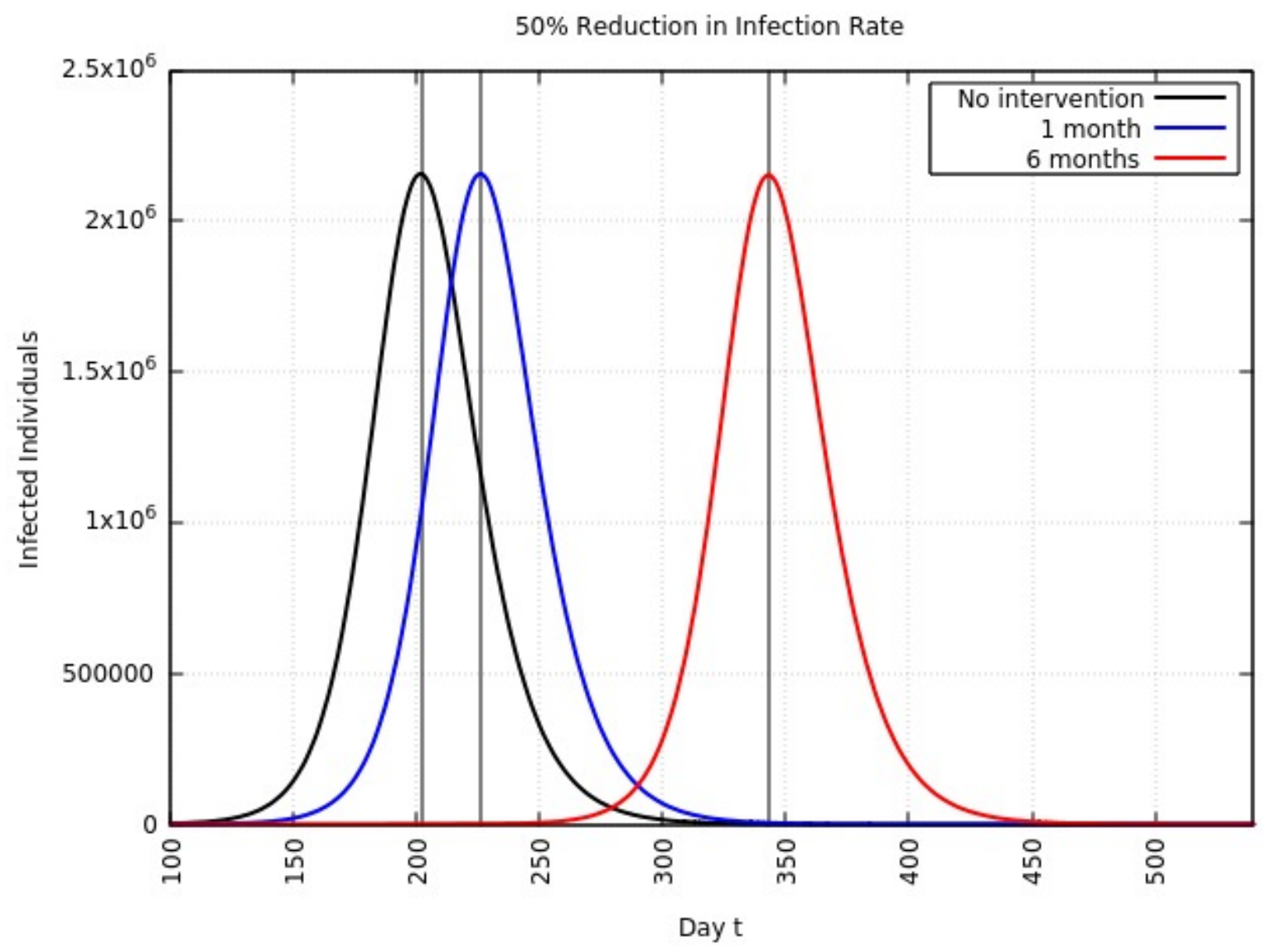

FIG. 7: Variation in $Y(t)$ for time $t, 0 \leq t \leq 550$ with no intervention, 1 month of intervention and 6 months of intervention with assumption of $\beta=0.50 \times 0.258$

\section{25\% Reduction in Infection Rate}

For a $25 \%$ reduction in the infection rate and one month of intervention, the estimated peak is delayed by 38 days. That is, pushed from 202 days to 240 days since day 0 (January $30,2020)$. For a $25 \%$ reduction in the infection rate and six months of intervention, the estimated peak is delayed by 234 days. That is, pushed from 202 days to 436 days since day 0 (January 30, 2020). This is represented in Figure 8.

A summary of all the delays in the estimated peaks can be found in Table III. 


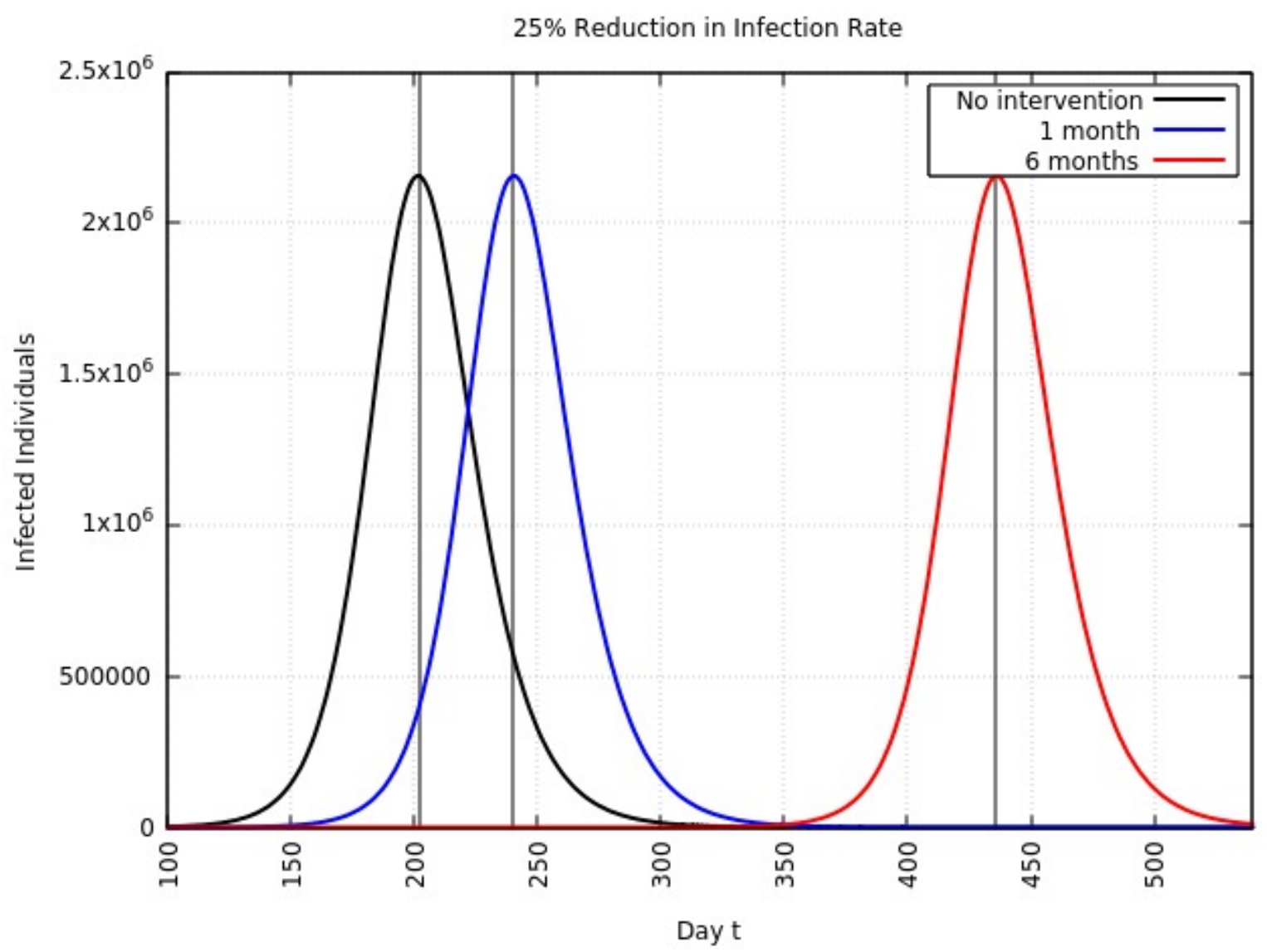

FIG. 8: Variation in $Y(t)$ for time $t, 0 \leq t \leq 550$ with no intervention, 1 month of intervention and 6 months of intervention with assumption of $\beta=0.25 \times 0.258$

TABLE III: Summary of change in estimated peak from August 11, 2020. Units are days. The 1 month and 6 months delays are the delays in the estimated peaks after respective intervention periods. The dates indicated are the revised dates of the estimated peaks.

\begin{tabular}{ccccc}
\hline \hline$\beta$ Drop & 1 Month Delay & Date & 6 Months Delay & Date \\
\hline $75 \%$ & 12 & August 23 & 68 & October 18 \\
$50 \%$ & 24 & September 4 & 141 & December 30 \\
$25 \%$ & 38 & September 18 & 234 & April 2, 2021 \\
\hline \hline
\end{tabular}

\section{Total Individuals Infected}

Upon integrating $Y(t)$ from Equation 3 over time $t$, we obtain an approximate of the total number of infected individuals over 550 days. With no intervention, the approximate 
medRxiv preprint doi: https://doi.org/10.1101/2020.04.20.20072793; this version posted April 24, 2020. The copyright holder for this preprint (which was not certified by peer review) is the author/funder, who has granted medRxiv a license to display the preprint in perpetuity.

It is made available under a CC-BY-NC-ND 4.0 International license .

total number of infected individuals will be $1.2087 \times 10^{8}$ which is $9 \%$ of the total population of India. With one month of intervention and $75 \%$ reduction in the infection rate, the approximate total number of infected individuals will be the same. But with six months of intervention and $75 \%$ reduction in the infection rate, the approximate total number of infected individuals will be $1.2002 \times 10^{8}$ compared to $1.2087 \times 10^{8}$ with no intervention. This

means approximately 850,000 individuals will not be infected. The change in these numbers for a higher reduction in infection rate does not significantly change the approximate total number of infected individuals. It only pushes the approximate epidemic peak to a later date.

\section{DISCUSSION}

From this work, by applying the SEIR compartmentalization model, it is clear that the COVID-19 epidemic peak can easily reach August, 2020. This prediction is sensitive to changes in the behavior of not only the virus but of people and their practice of social distancing. India is still in the process of gearing up its healthcare system and it currently may be ill equipped to deal with a large number of cases. Delaying the peak will ensure adequate medical equipment and personnel for all her citizens. The WHO has issued similar statements reiterating the importance of practicing social distancing to ensure that national health care systems are not strained.

Acknowledgements: The author would like to thank anonymous reviewers for their inputs

Conflicts of Interests: The author declares no conflict of interest

Declarations of Interest: None

Funding: None

\section{REFERENCES}

${ }^{1}$ Coronavirus disease (covid-19) pandemic. Available online: https://www . who.int/emer gencies/diseases/novel-coronavirus-2019. Accessed: 2020-03-15. 
medRxiv preprint doi: https://doi.org/10.1101/2020.04.20.20072793; this version posted April 24, 2020. The copyright holder for this preprint (which was not certified by peer review) is the author/funder, who has granted medRxiv a license to display the preprint in perpetuity. It is made available under a CC-BY-NC-ND 4.0 International license .

${ }^{2}$ The species severe acute respiratory syndrome-related coronavirus: classifying 2019-ncov and naming it sars-cov-2. Nature Microbiology, 5(4):536-544, Feb 2020.

${ }^{3}$ Catharine I. Paules, Hilary D. Marston, and Anthony S. Fauci. Coronavirus Infections-More Than Just the Common Cold.

${ }^{4} 2019$ novel coronavirus covid-19 (2019-ncov) data repository by johns hopkins csse. Available online: https://github.com/CSSEGISandData/COVID-19. Accessed: 2020-03-15.

${ }^{5}$ Rolling updates on coronavirus disease (covid-19). Available online: https://www. who . int/emergencies/diseases/novel-coronavirus-2019/events-as-they-happen. Accessed: 2020-03-12.

${ }^{6}$ Janta curfew just the beginning of a long battle against coronavirus: Pm modi. Available online: https://www.indiatoday.in/india/story/janta-curfew-just-beginnin g-long-battle-against-coronavirus-pm-modi-1658528-2020-03-22. Accessed: 2020-03-23.

${ }^{7}$ Toshikazu Kuniya. Prediction of the epidemic peak of coronavirus disease in japan, 2020. Journal of Clinical Medicine, 9(3):789, 2020.

${ }^{8}$ Natalie M. Linton, Tetsuro Kobayashi, Yichi Yang, Katsuma Hayashi, Andrei R. Akhmetzhanov, Sung-Mok Jung, Baoyin Yuan, Ryo Kinoshita, and Hiroshi Nishiura. Incubation period and other epidemiological characteristics of 2019 novel coronavirus infections with right truncation: A statistical analysis of publicly available case data. Journal of Clinical Medicine, 9(2):538, 2020.

${ }^{9}$ Haoxuan Sun, Yumou Qiu, Han Yan, Yaxuan Huang, Yuru Zhu, and Song Xi Chen. Tracking and predicting covid-19 epidemic in china mainland. medRxiv, 2020.

${ }^{10}$ Projected population statistics. Available online: https://data.gov.in/resources/ projected-population-characteristics-1st-march-2013-2001-2026-india. Accessed: 2020-03-20.

${ }^{11}$ Ministry of health and family welfare - covid-19 statewise status. Available online: https: //www.mohfw.gov.in/. Accessed: 2020-03-18.

${ }^{12}$ Pauline [van den Driessche]. Reproduction numbers of infectious disease models. Infectious Disease Modelling, 2(3):288 - 303, 2017.

${ }^{13}$ Coronavirus: India enters 'total lockdown' after spike in cases. Available online: https: //www.bbc.com/news/world-asia-india-52024239. Accessed: 2020-03-25.

${ }^{14}$ How rapidly can covid-19 spread in india? government did the math. Available online: 
medRxiv preprint doi: https://doi.org/10.1101/2020.04.20.20072793; this version posted April 24, 2020. The copyright holder for this preprint (which was not certified by peer review) is the author/funder, who has granted medRxiv a license to display the preprint in perpetuity. It is made available under a CC-BY-NC-ND 4.0 International license.

https://www.ndtv.com/india-news/coronavirus-outbreak-15-lakh-delhi-cov id-19-cases-in-optimistic-scenario-centres-estimate-2199464. Accessed: 2020-03-25.

${ }^{15}$ Coronavirus: India's restrictive criteria for testing may mask toll. Available online: https: //www . indiatoday . in/india/story/coronavirus-covid-19-testing-india-16567 28-2020-03-18. Accessed: 2020-03-18. 
$75 \%$ Reduction in Infection Rate

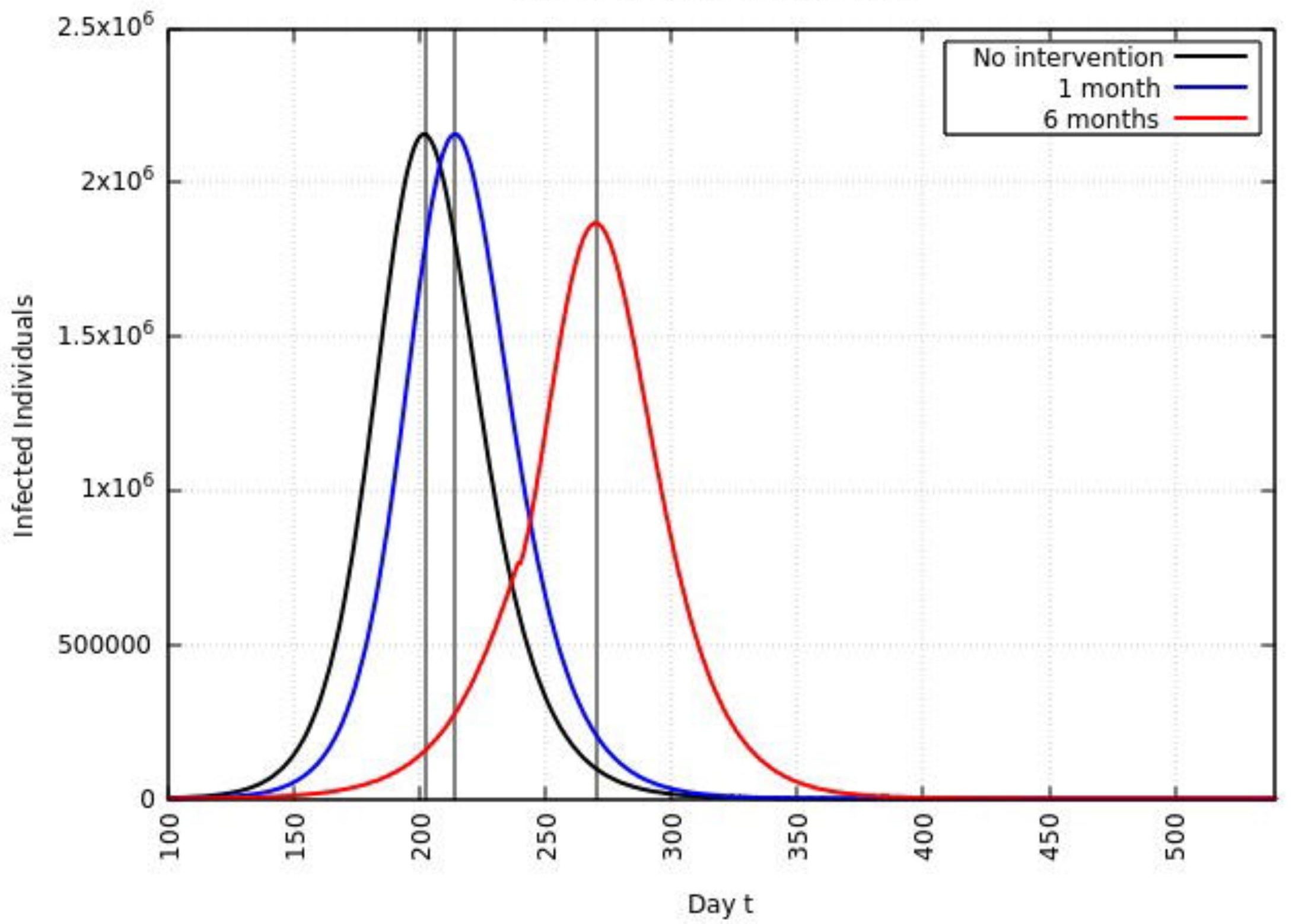


Estimate of Infected Individuals and New Confirmed Cases

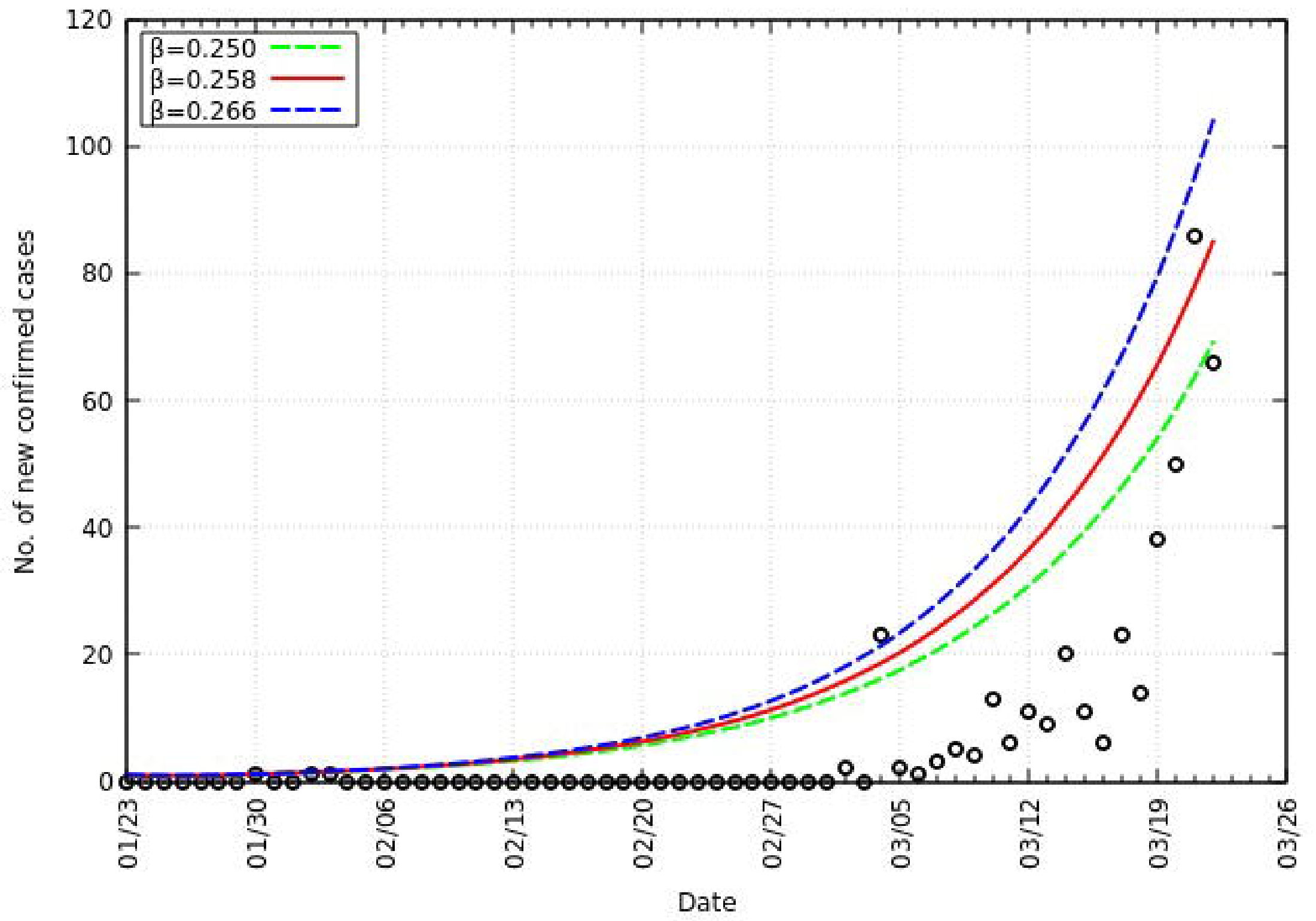


Change in Confirmed Cases in India

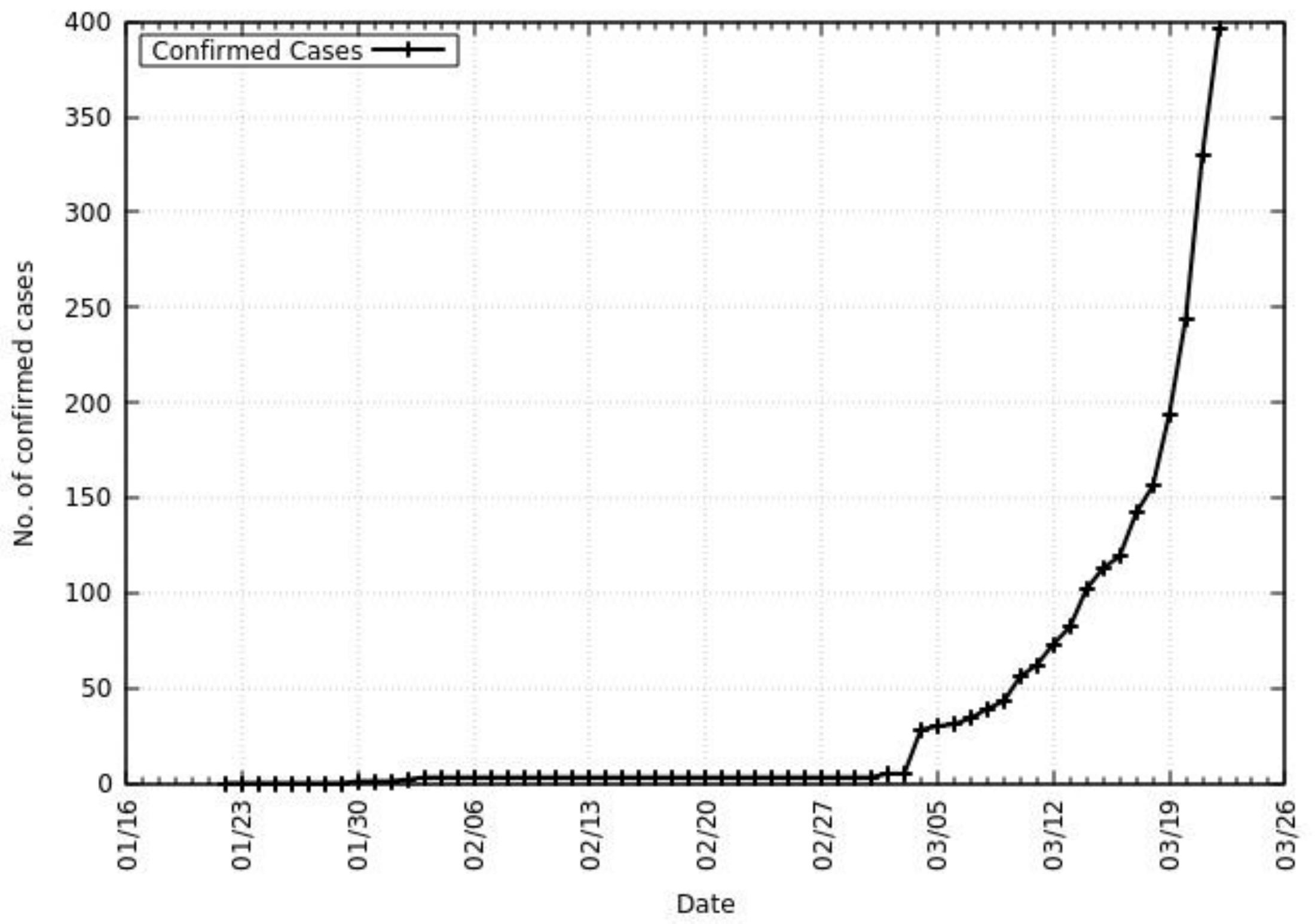


Confirmed Cases in India

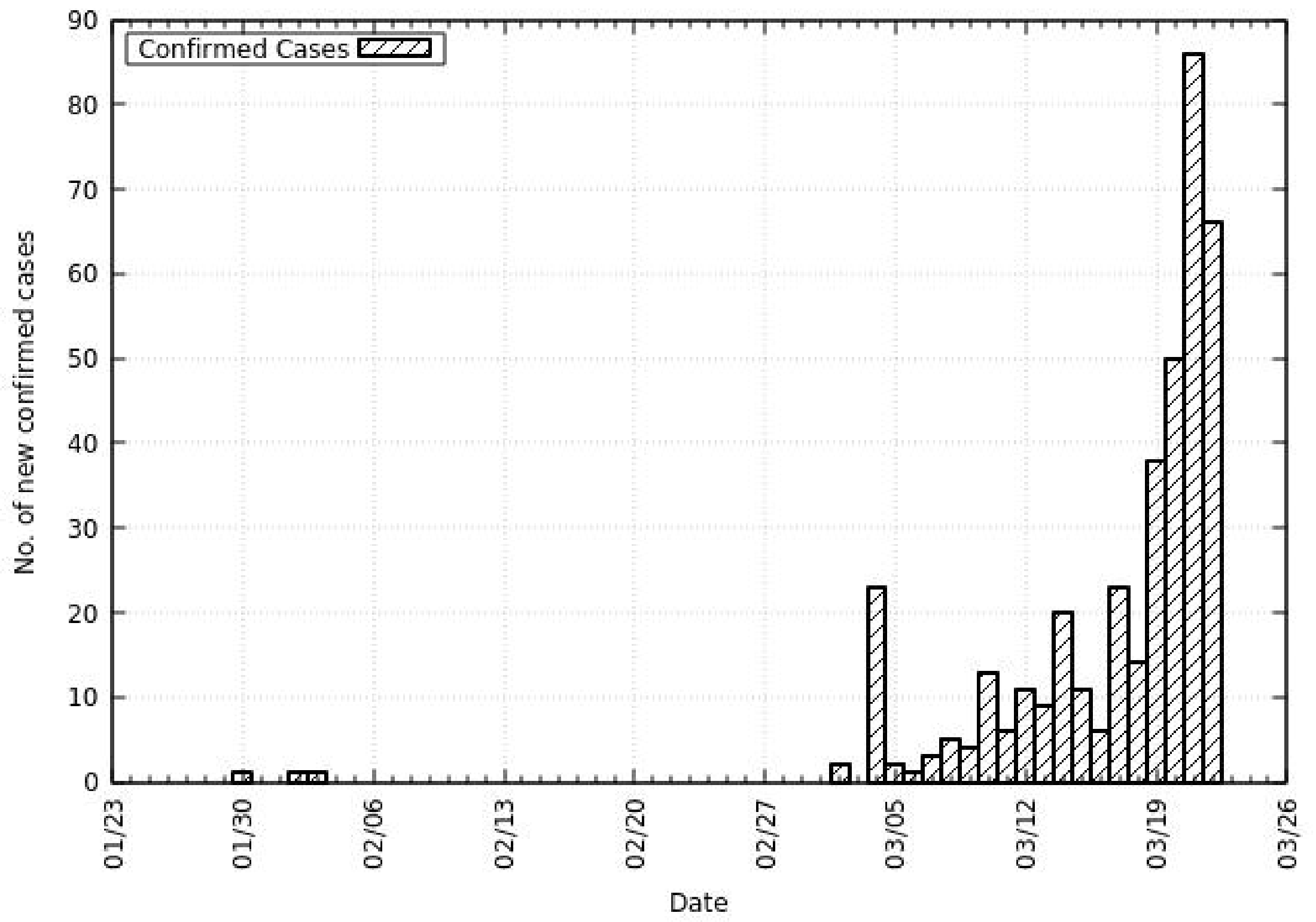

